\title{
Development of a Purchasing and Supply Management Maturity Framework
}

\author{
Jörg Schweiger \\ Department of Industrial Management, University of Applied Sciences JOANNEUM, \\ 8605 Kapfenberg, Austria \\ E-mail: joerg.schweiger@fh-joanneum.at \\ Department of Electrical, Managerial and Mechanical Engineering, University of Udine, \\ 33100 Udine, Italy
}

\begin{abstract}
The goal of this contribution is to present a Purchasing and Supply Management Maturity Framework based on the findings of a comprehensive literature and empirical research and a comparative analysis of maturity models published between 1983 and 2014 as well as (management) frameworks published between 1998 and 2014 in Purchasing and Supply Management (PSM). In total 20 maturity models published from authors with an academic or scientific background, 18 maturity models offered from consulting firms and 19 management frameworks of purchasing management were examined. In this research the following eight modules that contribute to a mature and professional PSM were detected: (1) strategy \& plans, (2) controlling \& performance management, (3) organization \& internal interfaces, (4) supplier management \& external interfaces, (5) process excellence \& information and communication technology (ICT), (6) talents \& skills, (7) innovation \& methods and (8) sustainability \& ethics. Based on these findings, the concept of an original Purchasing Maturity Framework will be presented. Contrary to the large part of the published maturity models in PSM, this model is rather designed as a management model for (I) the assessment of the PSM maturity in a company and (II) the display of standard improvement paths that should lead to higher maturity than an assessment tool for evaluating the maturity at a certain point in time. Moreover, aspects of professional project and change management will be addressed that are necessary for an effective and efficient advancement of the PSM function in a company.
\end{abstract}

Keywords: purchasing maturity, purchasing framework, purchasing excellence

\section{INTRODUCTION}

Purchasing and Supply Management is an important and crucial function in a company. One main cause is the leverage effect of PSM on the operating result: With an up to 60 percent share of total revenue, the costs for purchased parts have a tremendous effect on the bottom line in the main industries like metal, automotive or electronics (Arnolds et al., 2013; Wallner and Schweiger, 2012; Klein, 2012; BME, 2011; Ortner et al., 2011; Ballou, 1998). Besides this economic impact, the PSM function in a company is directly affected by major internationally driven business trends like globalization, short product life-cycles, high volatility and risks on the (raw material) market, complex supply chain structures, sustainability issues or intellectual property protection (Aberdeen, 2014; Roland Berger, 2014; Spina et al., 2013; Tate et al., 2013; Wildemann, 2008; Beamon, 2008). These current aspects and challenges lead to a steadily increasing set of goals the PSM department has to fulfill. Next to the traditional and mostly operational objective to ensure the security of supply to low costs and high quality standards (Cousins et al., 2008; Arnolds et al., 1998; Kluck, 1998; Eschenbach, 1990), more strategic goals with mid- to long-term orientation came on the agenda of PSM executives. Examples are contributing to product design and innovation through early (supplier) involvement (Roland Berger, 2014; Axelsson et $a$ l., 2006), building differentiated sourcing strategies and supplier partnerships (Aberdeen, 2014; Ortner et al., 2011), evaluating the "right" organizational structure (e.g. central, hybrid, decentral; Offshoring, Onshoring; Benton, 2010; Monczka, 2010; Cousins, 2008), starting corporate social responsibility (CSR) and green procurement initiatives (van Weele, 2010; Burt et al., 2003), establish early warning and risk management systems (A.T. Kearney, 2011) or to ensure highly efficient PSM processes within the company and with the most important suppliers using the proper ICT (Spring Procurement, 2010).

To cope with that a high level of professionalism and innovative orientation in the purchasing function is crucial (Schweiger, 2014; Rozemeijer et al., 2003). In this context it is interesting for both academics and practitioners to answer the following question: What is a professional and strategic oriented PSM department? In this respect, purchasing maturity models (PMM) can be applied. Over the last decades several scientific as well as practical oriented PMM have been developed, that describe "several stages an organization is expected to go through in its quest for greater sophistication" (Schiele, 2007, p.274). These models offer many suggestions what a company - and in this specific context the PSM department - should do to reach the next maturity level. The hypothesis is that mature purchasing organizations apply best practices, while unsophisticated organizations fail to employ them (Ellram et al., 2002; Chiesa et al., 1996). The assumption is that greater maturity is associated with better (business) performance.

Parallel to that, (management) frameworks in PSM (e.g. Four Pillars of Purchasing and Supply Chain Excellence by Monczka et al (2010); Framework for Managing External Resources by EFQM (2006); House of Sourcing and Supply Management by Eßig (2004)) also 
deliver some helpful aspects and a theoretical systemization of holistic and structured purchasing management (Ortner and Schweiger, 2010; Baier, 2008), why the analysis of these frameworks also helps to answer the raised question above.

Up to know, a consistent, current and transparent overview and substantial alignment of purchasing maturity models (scientific and practical oriented) as well as management frameworks in Purchasing and Supply Management (PSMF) is still missing (research gap), but necessary to rank the most important issues of maturity in PSM as a guideline for PSM professionals. Furthermore, the existing maturity models do not take contextual aspects into account and focus primarily on the maturity assessment and not on the improvement phase of PSM, what lead to a further need of research. Usually PSM executives see (too) many things to (concurrently) improve (Stolle, 2007), but the link from the initiatives to the overall PSM and firm's performance is not always easy to determine. Moreover, the handling of too many initiatives and actions alongside daily business inevitably leads to more diversity and complexity for the employees in the purchasing department, which may again provoke counter-productive effects (Schweiger, 2014). This is a serious aspect, especially for small and medium sized companies with limited organizational resources as well as an operational focus on getting the materials to a good price, in the defined quality and in time (Sollish and Semanik, 2012).

Based on the facts above, it appears crucial to continue the research about the critical aspects of high PSM maturity, and to develop a supportive management framework for assessing and interpreting the PSM maturity in a company until the realization of the improvement initiatives that should lead to higher sophistication.

\section{RESEARCH GOALS AND METHODOLOGY}

The main goal of this contribution is to present an overview of the published maturity models in scientific literature as well as management-oriented models offered from specialized consulting companies in this field over the last three decades. The focus lies on the areas of maturity assessment covered in these models. Parallel (management) frameworks in PSM will be analyzed and the findings of both will be aligned (Table 1).

Table 1 Research Goals

\begin{tabular}{|c|c|}
\hline Research Goal 1 & Develop a historical overview of maturity models and frameworks in Purchasing and Supply Management. \\
\hline Research Goal 2 & $\begin{array}{c}\text { Derive the most important areas that decide about the maturity level of a purchasing department based on } \\
\text { PMM and PSMF as basis for the development of an original Maturity Framework in PSM. }\end{array}$ \\
\hline
\end{tabular}

After defining the two research goals, the clarification of the research methodology is the next step. In general, the research topic can be allocated to the field of managerial economics and management science. Within this research field the problems that lead to new research activities mainly appear in practice (Ulrich, 1984), why managerial economics can be defined as part of the applied sciences (Schreyögg, 2007). Based on existing and scientifically grounded results combined with conceptual research activities recommendations and solutions should be derived. In general, it can be distinguished between explanatory and exploratory research. Whereas the explanatory research is focusing on testing hypothesis, the exploratory research aims at contributing in a field that previously has been subject to little research. By doing that, a profound basis is created for further hypothesis testing. As it will be shown in this article, there is not that much-detailed research in the area of purchasing maturity models as well as in the area of management frameworks in PSM over the last decades. That is why the exploratory research approach was chosen. The goal is rather to create new insights and knowledge in the area of holistic Purchasing and Supply Management than to an empirical verification or falsification of a single aspect of PSM.

In order to give a critical, objective and transparent overview of the existing models and frameworks in PSM, a literature review was conducted (Rousseau et al., 2008). By analyzing the relevant literature, patterns, themes and critical issues concerning the research question can be identified (Seuring et al., 2005). Therefore, the list with the most important peer-reviewed journals in PSM, analytically derived from Wynstra (2010), was taken as a basis and was extended with other scientific journals and databases in the PSM area (Table 2).

Table 2 Selected Journals for Literature Review

\begin{tabular}{|c|c|}
\hline & Table 2 Selected Journals for Literature Review \\
\hline & - Journal of Purchasing and Supply Management \\
Relevant PSM journals based & - Supply Chain Management: An International Journal \\
on an analysis of the years & - International Journal of Operations and Production Management \\
1999-2008 (Wynstra, 2010) & - International Journal of Production Economics \\
& - International Journal of Production Research \\
& - Journal of Business and Industrial Marketing \\
& - Journal of Business Research \\
& - Journal of Operations Management \\
& - Industrial Marketing Management \\
\hline Extended list & - Journal of Business Logistics \\
& - Supply Chain Management Review \\
& - MlT-Sloan Management Review \\
& - Industrial Management \\
\hline
\end{tabular}


Table 2 Selected Journals for Literature Review (Con't)

\begin{tabular}{|c|c|}
\hline scientific databases & $\begin{array}{ll}\text { - } & \text { Emerald } \\
\text { - } & \text { ABI/Inform Global - T\&I ProQuest } \\
\text { - } & \text { EBSCO Business Source Premier } \\
\text { - } & \text { Wiley }\end{array}$ \\
\hline $\begin{array}{c}\text { (highly cited) academic } \\
\text { textbooks }\end{array}$ & $\begin{array}{l}\text { - } \text { Bhote: Strategic Supply Management (1989) } \\
\text { - } \quad \text { Hahn/Kaufmann: Handbook of Industrial Purchasing Management (2002) } \\
\text { - } \quad \text { Burt et al.: World Class Supply Management (2003) } \\
\text { - } \text { Axelsson et al.: Developing Sourcing Capabilities (2005) } \\
\text { - } \quad \text { Cousins et al.: Strategic Supply Management (2008) } \\
\text { - } \quad \text { Monczka et al.: Purchasing \& Supply Management (2010) } \\
\text { - } \quad \text { Benton: Purchasing and Supply Chain Management (2010) } \\
\text { - } \text { Van Weele: Purchasing and Supply Chain Management (2010) } \\
\text { - } \quad \text { Lysons/Farrington: Purchasing and Supply Chain Management (2012) } \\
\text { - } \quad \text { Sollish/Semanik: The Procurement and Supply Manager's Desk Reference (2012) }\end{array}$ \\
\hline
\end{tabular}

In order to identify the relevant contributions for the defined research goal, an iterative approach has proven to make particular sense (Sartor et al., 2013; Seuring et al., 2005). As a first step a (1) title search for the mentioned journals for the period 1984-2014 was carried out, followed by a (2) keyword search (all except full text). The initial keywords were "Purchasing Maturity", "Supply Management Maturity", "Procurement Maturity", "Supply Chain Management Maturity", "Supply Maturity" and "Maturity models". Subsequently and based on the first results, the following keywords were added to the keyword search: "Purchasing Excellence", "Supply Management Excellence", "Procurement Excellence", "Supply Chain Management Excellence", "Supply Excellence", "Purchasing Audit", "Supply Management Audit", "Procurement Audit", "Supply Chain Management Audit", "Purchasing Power", "Supply Management Power", "Supply Chain Management Power", "Procurement Power", "Worlds Class Purchasing", "World Class Supply Management", "World Class Supply Chain Management" and "World Class Procurement".

The detailed analysis of maturity models in PSM was the primary focus and inner kernel of the research (Figure 1). However, during the title search in the mentioned journals particular attention has also be given to keywords that indicate if a management framework in PSM was discussed in the paper.

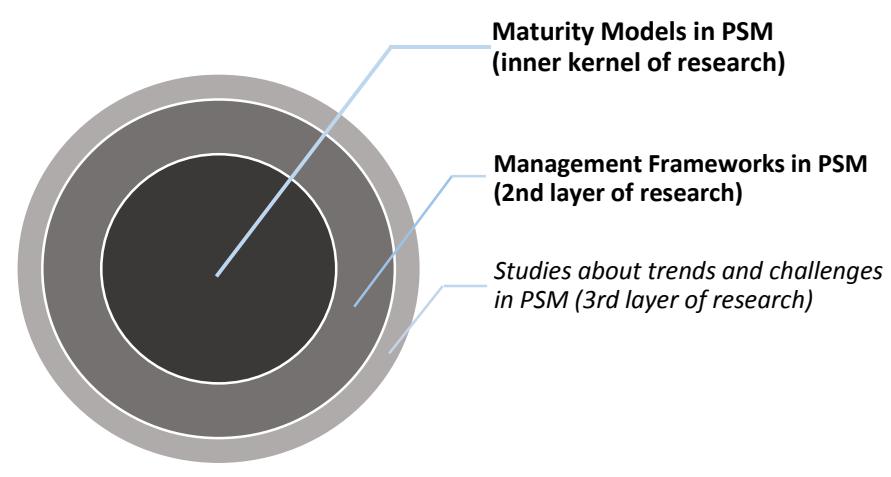

Figure 1 Layers of Research

The relevant respective keywords were "Purchasing Framework", "Supply Management Framework", "Procurement Framework", "Supply Chain Management
Framework", "Supply Framework", "Purchasing Model", "Supply Management Model", "Procurement Model", "Supply Chain Management Model" and "Supply Model". The third layer of research - but not discussed in this paper in detail - was the analysis of studies about trends and challenges in PSM (e.g. Aberdeen, 2014; Roland Berger, 2014; Spina at el., 2013; Porsche Consulting, 2012; A.T. Kearney, 2011). The motivation for this research step is to find out if there are new challenges and trends, which are not covered from the available models in literature. By combining the results from the analysis of PMM, PSMF as well as PSM studies a well grounded basis for developing an original Purchasing and Supply Management Maturity Framework can be established.

Simultaneously to the keyword search in the mentioned journals, a (3a) crosscheck was undertaken by searching the electronic databases Emerald, ABI/Inform Global - T\&I ProQuest, EBSCO Business Source Premier and Wiley separately and (3b) by searching highly cited academic textbooks. For a final countercheck and as a necessary means of empirically gaining information about management oriented maturity models, a (4) keyword search on www.google.de was conducted. At the same time (5) webpages of specified consulting companies in the area of PSM (Forbes- and Vault-Ranking of TOP-Consulting Companies; Brand Eins, Special Edition "Consulting Companies") and well known PSM institutions were searched for useful information and if possible a direct contact by mail and telephone was established (Table 3 ).

\section{MATURITY MODELS AND FRAMEWORKS IN PSM}

At this stage of research (09/2014), it was possible to deduce a list of 20 scientific maturity models and 18 management-oriented models that include both operational and strategic aspects of holistic PSM. Purchasing maturity models with a focus on single PSM aspects were excluded. Examples are maturity models in the area of supplier integration/supply chain integration from Childerhouse et al. (2011) or Fawcett (2008), supply chain operations from Netland (2011), global sourcing maturity from Trent/Monczka (2005) and Cox (1996) or a maturity model concerning MRO purchasing from Barry/Cavinato (1996). Parallel to that 19 (management) frameworks in PSM were examined. 
Table 3 Consulted PSM Consultants and Institutions

Table 3 Consulted PSM Consultants and Institutions
\begin{tabular}{|c|l|}
\hline $\begin{array}{c}\text { Contacted Consulting } \\
\text { companies }\end{array}$ & $\begin{array}{l}\text { Accenture, adcpi Consulting, ADR international, Arthur D. Little, A.T. Kearney, Bain \& Company, Boston } \\
\text { Consulting Group, Bearing Point, booz\&co, Cell Consulting, Effico-Consulting, futurepurchasing, H \& Z, Horváth } \\
\text { und Partner, Innovative Management Partner, Insight Sourcing Group, Kerkhoff Consulting, McKinsey, MHP, } \\
\text { OC\&C Strategy Consultants, Oliver Wyman, OptiAchats, PA Consulting Group, pm2Consult, PMMS Consulting } \\
\text { Group, Porsche Consulting, Purspective, PricewaterhouseCoopers, Roland Berger, Sourceone Management } \\
\text { Services, Spring Procurement, Strategic Procurement Solutions, synGroup }\end{array}$ \\
\hline \multirow{5}{*}{ PSM organizations } & Aberdeen Group, CAPS Research/University of Arizona, Chartered Institute of Purchasing \& Supply \\
& Management, European Association of Purchasing Managers/Bundesverband für Materialwirtschaft, Einkauf \\
& und Logistik e.V (BME), European Foundation for Quality Management, Gartner Group, Institute of Supply \\
& Management, International Purchasing and Supply Education and Research Association, National Procurement \\
& Institute, Supply Chain Council, Supply Chain Management Association, The Institute for Public Procurement, \\
& The International Federation of Purchasing and Supply Management \\
\hline
\end{tabular}

\subsection{Purchasing Maturity Models}

In the following two tables the scientific and the management oriented purchasing maturity models are listed. Next to the name of the model, the corresponding author(s), the year of publication as well as the number of maturity levels are shown in a historical descending order.

Table 4 List of Scientific Purchasing Maturity Models

\begin{tabular}{|c|l|l|c|c|}
\hline Nr. & Name of PMM & Author(s) & Year & Levels \\
\hline 1 & PSM drivers and firm performance & Hartmann et al. & 2012 & 3 \\
\hline 2 & Supply Chain Maturity Model & Reyes/Giachetti & 2010 & 5 \\
\hline 3 & Purchasing and supply development model & Van Weele & 2010 & 6 \\
\hline 4 & Stages in purchasing strategy development & Monczka et al. & 2010 & 4 \\
\hline 5 & Supply Management Maturity Model & Schiele & 2007 & 4 \\
\hline 6 & Conceptual model of drivers of PSM evolution & Stolle & 2007 & 3 \\
\hline 7 & Levels of strategic purchasing & Paulraj et al. & 2006 & 3 \\
\hline 8 & Purchasing Function Maturity & Cousins et al. & 2006 & 4 \\
\hline 9 & Purchasing function maturity & 2005 & 5 \\
\hline 10 & Supply chain management process maturity model & Bruel/Petit & 2004 & 5 \\
\hline 11 & World Class Supply Management & Lockamy/McCormack & 2002 & 1999 \\
\hline 12 & Purchasing development stages & Burt/Starling & 1998 & 5 \\
\hline 13 & Purchasing development model & Jones & 1996 & 6 \\
\hline 14 & From reactive to strategic procurement & Van Weele et al. & 4 \\
\hline 15 & Purchase position benchmarking & Dobler et al. & $1989 / 1994$ & 3 \\
\hline 16 & American Keiretsu & Sysons & 1992 & 4 \\
\hline 17 & Towards purchasing excellence/MSU & Burt/Doyle & $1991 / 1992$ & 10 \\
\hline 18 & Fitting purchasing to the strategic firm & Monczka/Trent & 1990 \\
\hline 19 & The four stages of supply management & Freeman/Cavinato & 1989 & 4 \\
\hline 20 & Strategic stages in purchasing & Bhote & 1988 & 4 \\
\hline
\end{tabular}

As table four shows, the different PMM distinguish between three to ten different maturity levels (see also Schumacher et al., 2008 and Schiele, 2007). The average of maturity levels is between four to five. The mentioned models describe one final stage a company is expected to reach in order for being "world class". This issue needs further research, which also considers various contextual aspects. Also, it is highly unlikely and nearly impossible to apply a single PMM to all types of companies and branches; however this is what most of these models do. As an example, there must be rather one most appropriate maturity level depending on the business and corporate context (e.g. Rozemejer et al., 2003; Keough, 1993) and not one best maturity point. Especially when thinking of the imbalance of power between a big supplier and a small buying firm some maturity aspects like "supplier integration with VMI" or "long term contracts to fix optimum price level" would be theoretically right but in most of the practical cases unrealistic. This suggests that there is one highest maturity point to be reached in theory (HTMP), and one that can be realistically achieved because of contextual aspects (highest realistic maturity point, HRMP).
Next to these listed models (PMM in a narrower sense) there are also some other maturity models that are not differentiating between concrete maturity levels, but also describing aspects and criteria for PMM and an assessment method (PMM in a broader sense). Examples are the Purchasing Management Audit approach by Scheuing (1989) or the 15M Strategy Scan by Heß (2009). Whereas some authors deduced the maturity aspects mainly from theory (e.g. Van Weele, 2010/1998, Monczka et al., 2010; Dobler et al., 1996; Sysons, 1989/1994), others also included the opinion of (practical) experts (e.g. Paulraj et al., 2006; Burt and Doyle, 1994; Freeman and Cavinato, 1990; Bhote, 1989; Reck and Long, 1988) in form of interviews or applying the Delphi method (Reyes and Giachetti, 2010). Only seven models have been empirically tested so far (Hartmann et al., 2012; Reyes and Giachetti, 2010; Schiele, 2007; Cousins et al., 2006; Paulraj et al., 2006; Lockamy and McCormack, 2004 and Monczka and Trent, 1991/1992).

15 out of 33 consulting companies or PSM organizations (Table 3) are offering detailed information concerning their PMM or replied on the request if they ever had a PMM in their portfolio and forwarded direct feedback 
or detailed further information. Some of them - like McKinsey or Arthur D. Little - changed the name of their PMM over the time and carried out some adaptions. There is also a close interrelation between the models from Arthur D.
Little, IMP Consulting and Cell Consulting (together with University St. Gallen) as those are based on the Purchasing Performance Index from 2002 (Vollrath and Nase, 2003 and Vollrath, 2006).

Table 5 List of Management Oriented Purchasing Maturity Models in Alphabetical Order

\begin{tabular}{|c|c|c|c|}
\hline Nr. & Name of PMM & Author(s) & Levels \\
\hline 1 & Assessment of Excellence in Procurement & A.T. Kearney & 2 \\
\hline 2 & Best in class maturity framework & Aberdeen & 3 \\
\hline 3 & Best Value Procurement & ADC Performance Improvement & $--^{*}$ \\
\hline 4 & Framework for managing external resources & EFQM & 3 \\
\hline 5 & $\begin{array}{l}\text { Management-oriented purchasing analysis } \\
\text { (Schumacher et al., 2008) }\end{array}$ & $H \& Z$ & 4 \\
\hline 6 & $\begin{array}{l}\text { Levels of Procurement development } \\
\text { (Anderson and Katz, 1998) }\end{array}$ & Mercer & 4 \\
\hline 7 & Purchasing Excellence & Roland Berger & 3 \\
\hline 8 & Purchasing EmPowerment (Voegele and Schwientek, 2002) & Roland Berger & 3 \\
\hline 9 & Purchasing Performance Index & $\begin{array}{c}\text { Cell Consulting/ } \\
\text { University St. Gallen }\end{array}$ & 4 \\
\hline 10 & Purchasing Maturity Model & OptiAchats & 4 \\
\hline 11 & Purchasing Value Excellence & \multirow{2}{*}{ Arthur D. Little } & 4 \\
\hline 12 & Purchasing Performance Excellence & & 4 \\
\hline 13 & Procurement Performance Excellence & Innovative Management Partner & 5 \\
\hline 14 & SCORmark & Supply Chain Council & 4 \\
\hline 15 & Stages of purchasing sophistication (Kraljic, 1983) & \multirow{2}{*}{$\begin{array}{l}\text { McKinsey \& } \\
\text { Company }\end{array}$} & 4 \\
\hline 16 & Stages of purchasing maturity (Cammish and Keough, 1991; Keough, 1993) & & 5 \\
\hline 17 & $360^{\circ}$ Supply Management Efficiency Review & $\begin{array}{l}\text { Strategic Procurement } \\
\text { Solutions }\end{array}$ & $-^{*}$ \\
\hline 18 & $360^{\circ}$ Procurement Performance Analysis & Horváth \& Partners & 4 \\
\hline
\end{tabular}

${ }^{*}$ At the time of handing in this paper, the information about the number of maturity levels from these three models was not yet available

When the name of the author/s is/are added in brackets (Table 5), publications (journals or books) are available for this PMM. In the other cases, the information was empirically gathered from the respective website or from directly contacting and interviewing the company.

As scientific models, also the management-oriented PMM distinguish between different levels of maturity. The number of stages here ranges between three (Purchasing EmPowerment) and five (e.g. Stages of purchasing maturity). The main difference is that the authors of the management-oriented models emphasize on the integration of their consulting experience into their PMM. Scientific and academic findings are of course indirectly integrated into these models, but the consideration of specialized expertise and thorough knowledge of various industries makes them unique. For assessing the PSM maturity the management-oriented PMM usually follow a two-step approach. First, the respective company is asked to fill out a questionnaire for a self-assessment and subsequently gets a first feedback about the performance in each of the evaluation areas (e.g. Innovative Management Partner, OptiAchats). Based on that, detailed fee-based workshops, analyses (e.g. spend analysis) and interviews are usually offered in order to derive rooms for improvement.

\subsection{Frameworks in PSM}

Taking the overview of management framework in PSM from Ortner and Schweiger (2010, p.128) as a basis (seven models), it was possible to extend this list by carrying out the above described literature research up to 19 frameworks. These models offer a comprehensive view on the aspects a company has to take into consideration for a well-managed PSM (Ortner and Schweiger, 2010).

Table 6 List of (management) Frameworks in PSM

\begin{tabular}{|c|l|l|c|}
\hline Nr. & Name of PSMF & Author(s) & Year \\
\hline 1 & SCOR Model & SCC & 2012 \\
\hline 2 & Management of Requirements in Collaborations & Ortner et al. & 2011 \\
\hline 3 & 3-Layer-Model of SRM & Appelfeller/Buchholz & 2011 \\
\hline 4 & Integrated PSM Process & Benton & 2010 \\
\hline 5 & Four Pillars of Purchasing and Supply Chain Excellence & Monczka et al. & $2009 / 2010$ \\
\hline 6 & 15M-Architecture of supply strategy & Heß & $2009 / 2010$ \\
\hline 7 & Cycle of holistic purchasing management & Schweiger et al. & 2009 \\
\hline 8 & Potential Analysis in Purchasing & Wildemann & 2008 \\
\hline
\end{tabular}


Table 6 List of (Management) Frameworks in PSM (Con't)

\begin{tabular}{|r|l|l|c|}
\hline 9 & Framework of purchasing activities & Schentler & 2008 \\
\hline 10 & Procurement Event Monitoring & Bäck et al. & 2007 \\
\hline 11 & The strategic supply wheel & Cousins & $2002 / 2008$ \\
\hline 12 & House of Sourcing and Supply Management & Eßig & 2005 \\
\hline 13 & Supply Management Navigator & Jahns & 2005 \\
\hline 14 & The 21st Century Logistics framework & Closs/Mollenkopf & 2004 \\
\hline 15 & The CIPS procurement and supply management model & CIPS, Lysons/Farrington & 2003 \\
\hline \multirow{2}{*}{16} & Supply Chain Management Excellence Model & Kanji/Wong & $1999 / 2003$ \\
\cline { 2 - 4 } & & Bowersox et al. & 1999 \\
\hline 17 & PSM: a conceptual framework & Kaufmann & 2002 \\
\hline 18 & Integrated St. Galler purchasing management approach & Schober et al. & 2001 \\
\hline 19 & Global Supply Chain Forum Framework & Cooper et al. & 1997 \\
\cline { 3 - 4 } & & GSCM & \\
\hline
\end{tabular}

Only models that are containing more than two areas of holistic PSM (e.g. Strategy, Organization and Processes or Organization, Processes and Performance Management) were considered for the in-depth analysis. Models that are only focusing on single aspects in PSM (e.g. Framework for low-cost country sourcing by Kusaba et al. (2011), Forward Sourcing by Appelfeller and Buchholz (2011), Advanced Sourcing by Wildemann (2009) or Framework of Purchasing Competence by Gonzales-Benito (2007)) were excluded.

\section{COMMON CONSENSUS OF PSM MATURITY}

For the development of the original PSM maturity framework it was interesting to find out if there is a common consensus about maturity in PSM. For that reason each of the assessment areas from the single maturity models as well as the Purchasing and Supply Management frameworks were listed and compared with each other in a matrix. By doing that, it was possible to detect the following eight main areas and in total 82 indicators of high PSM maturity by clustering the elements that substantially belong together.

Table 7 Areas and Indicators of High Maturity in PSM

\begin{tabular}{|c|c|c|}
\hline Nr. & Areas of Maturity & Indicators of high maturity in PSM (Excerpt) \\
\hline 1 & $\begin{array}{l}\text { Controlling \& } \\
\text { Performance } \\
\text { Management }\end{array}$ & $\begin{array}{l}\text { - Key performance indicators are defined and regularly reported. } \\
\text { - Based on the measured KPIs, initiatives for improvement are implemented. } \\
\text { - PSM is able to link its influence on the firm's overall performance. }\end{array}$ \\
\hline 2 & $\begin{array}{l}\text { Organization \& Internal } \\
\text { interfaces }\end{array}$ & $\begin{array}{l}\text { - Early involvement of PSM in product development projects. } \\
\text { - The needs of the internal and external customers are known and PSM regularly asks for feedback. } \\
\text { - There is a high visibility of the Purchasing Manager and the PSM team in the Board of Directors. The } \\
\text { PSM department is at a senior hierarchical level. At least PSM topics are regularly on the agenda of the } \\
\text { Top Management meetings. }\end{array}$ \\
\hline 3 & $\begin{array}{l}\text { Supplier (Relationship) } \\
\text { Management \& External } \\
\text { interfaces }\end{array}$ & $\begin{array}{l}\text { - A closed loop from supplier scouting and analysis until the supplier development is available and } \\
\text { documented. } \\
\text { - Supplier qualification programs and consistent supplier assessment methods are installed and feedback } \\
\text { of results as a basis for supplier development is forwarded. } \\
\text { - Supplier motivation programs or supplier awards are part of the companies' SRM. }\end{array}$ \\
\hline 4 & Strategy \& Plans & $\begin{array}{l}\text { - Based on a corporate strategy, PSM develops short-, mid- and long-term plans. } \\
\text { - The PSM team knows about the plans and can participate in the creation of the plans. } \\
\text { - The PSM team has detailed knowledge about sourcing-strategies for PSM (based on e.g. portfolios) and } \\
\text { apply them based on contextual situations. }\end{array}$ \\
\hline 5 & $\begin{array}{l}\text { Process Excellence \& } \\
\text { ICT }\end{array}$ & $\begin{array}{l}\text { - The core-processes are available in written form and part of a Purchasing Manual. } \\
\text { - For routine tasks and for decision support ICT is available and the PSM personnel is trained to use the } \\
\text { systems in an effective and efficient way. } \\
\text { - The PSM personnel has the right level of information concerning PSM specific ICT. }\end{array}$ \\
\hline 6 & Talents \& Skills & $\begin{array}{l}\text { - There is a structured skill and talent management for PSM employees, e.g. employees are sent for } \\
\text { internal and external education/training and job rotation is offered. } \\
\text { - The trainings activities are based on necessary current but also future requirements. } \\
\text { - Career paths and development programs for purchasing employees are available. }\end{array}$ \\
\hline 7 & Innovation \& Methods & $\begin{array}{l}\text { - Intensive use of strategic spend and cost management tools (e.g. LPP, CBD, Factor Cost Analysis). } \\
\text { - Regular benchmarking activities with our companies. }\end{array}$ \\
\hline
\end{tabular}


Table 7 Areas and Indicators of High Maturity in PSM (Con't)

\begin{tabular}{|c|l|l|}
\hline & $\begin{array}{l}\text { - For internal development programs of the PSM function methods of project management (e.g. CPM, } \\
\text { GANTT, milestones), creativity techniques (e.g. Ishikawa) and change management (e.g. motivation } \\
\text { techniques) are applied. }\end{array}$ \\
\hline 7 & Innovation \& Methods & $\begin{array}{l}\text { - There is a clear vision concerning Corporate Social Responsibility. } \\
\text { - A code of conduct is part of the supplier contract. } \\
\text { - Regular programs are carried out to increase transport efficiency and to reduce CO2 emission. }\end{array}$ \\
\hline
\end{tabular}

Schiele (2007) who also did a comparison between the PMM published between 1988 and 2006 chose the clusters "Planning", "Structural organization", "Process organization", "Human Resources", "Controlling" and "Collaborative supply relation". By doing so, especially the strategic, the innovative as well as the talent management and sustainable aspects are not sufficiently emphasized (even though they are partly integrated and addressed as sub-areas in his PMM), why a different classification and extension seem to be reasonable.

\section{PURCHASING AND SUPPLY MANAGEMENT MATURITY FRAMEWORK}

\subsection{Concept and Application}

The derived areas of maturity as well as the detailed indicators are the substantial construct for the development of the framework. Contrary to the discussed PMM the purchasing and Suppl y Management Maturity Framework (PSM2F) does not consist of a fixed number of maturity levels that are predefined. Following the concept of a framework as a management tool for PSM executives, the Purchasing and Supply Management Maturity Framework offers a comprehensive summary of indicators for high maturity in its kernel. For that reason, all the positively formulated aspects of maturity (things you should do/have) from the existing PMM as well as frameworks in PSM have been considered, as described by the following example using the PMM of Reck and Long from 1988 (Table 8). With this example it can be illustrated that positive aspects of maturity can be deduced from (nearly) every level and not only from the highest one. By breaking up this rigid and hence inflexible structure, the framework gives the company more flexibility in the creation of its individual improvement roadmap. By doing that, current resources, contextual aspects as well as overall corporate strategic goals can be considered in a better way, than by strictly following a predefined maturity ladder.

Table 8 Transfer of maturity aspects to $\mathrm{PSM}^{2} \mathrm{~F}$ using the PMM of Reck/Long

\begin{tabular}{|c|c|c|c|c|}
\hline \multicolumn{2}{|c|}{$\begin{array}{l}\text { Maturity Levels } \\
\text { (Reck/Long: Strategic } \\
\text { stages in Purchasing) }\end{array}$} & Description of maturity level (Excerpt) & $\begin{array}{c}\text { Evaluation of } \\
\text { wording } \\
\text { (positive/negative) }\end{array}$ & $\begin{array}{l}\text { Use for } \\
\text { PSM }^{2} F\end{array}$ \\
\hline \multirow{4}{*}{1} & \multirow{4}{*}{ Passive } & $\begin{array}{l}\text { The purchasing function has no strategic direction and primarily } \\
\text { reacts to the requests of other functions. }\end{array}$ & Negative & 凶 \\
\hline & & $\begin{array}{l}\text { High proportion of purchaser's time is spent on quick-fix and } \\
\text { routine operations. }\end{array}$ & Negative & 凶 \\
\hline & & $\begin{array}{l}\text { Purchasing function and individual performance are based on } \\
\text { efficiency measures. }\end{array}$ & Negative & 凶 \\
\hline & & $\begin{array}{l}\text { Little interfunctional communication takes place because of } \\
\text { purchasing's low visibility. }\end{array}$ & Negative & 凶 \\
\hline \multirow{4}{*}{2} & \multirow{4}{*}{ Independent } & $\begin{array}{l}\text { The purchasing function adopts the latest purchasing techniques } \\
\text { and practices. }\end{array}$ & Positive & $\square$ \\
\hline & & $\begin{array}{l}\text { The strategic direction of PSM is independent of the firm's } \\
\text { competitive strategy. }\end{array}$ & Negative & 凶 \\
\hline & & $\begin{array}{l}\text { Performance is primarily based on cost reduction and efficiency } \\
\text { measures. }\end{array}$ & Negative & 凶 \\
\hline & & $\begin{array}{l}\text { Coordination links are established between purchasing and } \\
\text { technical disciplines. }\end{array}$ & Positive & $\nabla$ \\
\hline \multirow{3}{*}{3} & \multirow{3}{*}{ Supportive } & $\begin{array}{l}\text { The purchasing function supports the firm's competitive strategy } \\
\text { by adopting purchasing techniques and practices. }\end{array}$ & Positive & $\square$ \\
\hline & & $\begin{array}{l}\text { Suppliers are considered a resource which is carefully selected } \\
\text { and motivated. }\end{array}$ & Positive & $\square$ \\
\hline & & $\begin{array}{l}\text { Markets, products and suppliers are continuously monitored and } \\
\text { analyzed. }\end{array}$ & Positive & $\square$ \\
\hline \multirow{3}{*}{4} & \multirow{3}{*}{ Integrative } & $\begin{array}{l}\text { Purchasing's strategy is fully integrated into the firm's competitive } \\
\text { strategy and PSM implements a strategic plan. }\end{array}$ & Positive & $\square$ \\
\hline & & Cross functional training of purchasing professionals. & Positive & $\square$ \\
\hline & & $\begin{array}{l}\text { Purchasing performance is measured in terms of contribution to } \\
\text { the firm's success. }\end{array}$ & Positive & $\square$ \\
\hline
\end{tabular}


In general, the framework consists of two main modules (Figure 2): First, an assessment module with a self-assessment area based on the indicators of high PSM maturity (Table 6), and a display area, where the subjective level of maturity is indicated and can be compared to the theoretical/scientific opinion about excellence (HTMP), or to the relevant industry benchmark (HRMP). To foster the contextual approach the respective company has the possibility to weight the maturity aspects or exclude aspects that are not important for their branch or business model (e.g. strong interrelation with $R \& D$ department is generally important but doesn't make sense for a trading company or a company with external R\&D).

Moreover the model contains recommendations in which areas an in-depth analysis - carried out in terms of a Purchasing Audit by a third party (van Weele, 2010; Scheuing, 1989) - might be useful (e.g. analyzing the compliance procedures or for areas where the experience of the PSM personnel is insufficient for an objective benchmark). After the assessment of the maturity level, standardized improvement paths and the respective positively influenced Key Performance Indicators will be displayed. By considering regular controlling loops and providing standard templates as well as assistance concerning change management aspects (e.g. create a culture of change and excellence, forming a powerful guiding coalition, empowering the personnel, plan and create short term wins, institutionalize new approaches; Champy, 1995; Kolmos and Graaff, 2007) this framework aims at covering the most important points for an effective and efficient advancement of the PSM function in a company.

A. Assessment
A.1. Self-Assessment
a.) Controlling \& Performance Management (CO)
b.) Organization \& Internal interfaces (ORG)
c.) Supplier (Relationship) Management \& External interfaces (SRM)
d.) Strategy \& Plans (S\&P)
e.) Process Excellence \& ICT (P\&IT)
f.) Talents \& Skills (T\&S)
g.) Innovation \& Methods (I\&M)
h.) Sustainability Issues (SUS)
A.2. Display of maturity...
a.) ...in comparison to theoretical/scientific optinion about
excellence.
b.)...in comparison to the relevant industry benchmark.
A.3. In-depth maturity assessment by a third party
". ...detailed spend analysis
". ...analysis of processes and documents
"...interviews with PSM personnel and relevant departments
B. Improvement
- Develop standardized improvement paths
- Controlling of realization
- Considering aspects of professional change management

Figure 2 PSM Maturity Framework

\subsection{Future Research Steps}

In a further step, at least 15 experts from specified consulting companies in the area of PSM (Forbes- and Vault-Ranking of TOP-Consulting Companies; Brand Eins, Special Edition "Consulting Companies"), as well as companies with certified PSM departments (e.g. European Association of Purchasing Managers/Bundesverband Materialwirtschaft, Einkauf und Logistik, BME; the Circle of Purchasing Executives of the Verein Netzwerk Logistik, VNL) or representatives of Best-Practice companies companies that have installed a Purchasing Manager in the Board of Directors or directly in the first reporting line to the CEO - from the industry will be interviewed. During the interviews, the preliminary results will be discussed and used for adapting and refining the Purchasing and Supply Management Maturity Framework (PSM2F). Finally, the framework will be tested in three case studies (Kähkönen, 2011) in 2015. Therefore, it will be introduced in three companies in the beginning of 2015. Based on the initial assessment, rooms for improvement will be deduced together with the company and responsibilities for the implementation and the controlling of the realization will be defined. In autumn, the assessment will be repeated in order to examine if there is an improvement due to the adoption of the theoretical advice and to evaluate which elements of change and project management were particularly helpful in the process of developing the PSM function to a higher maturity level. This approach of accompanying a company over a longer period of time using the PMM as a management framework and not only to examine the maturity level at a single point of time is a still unexplored area of research (Reyes/Giachetti, 2010). Doing that, it is possible to study the causal strength between assessing the purchasing maturity, adopting the improvement advice under consideration of change and project management aspects and actual long-term improvements.

\section{CONCLUSIONS}

The goal of this contribution was to present a concept of an original Purchasing and Supply Management Maturity Framework based on the findings of a comprehensive literature and empirical research in form of expert interviews and an extensive online research and a comparative analysis of maturity models as well as (management) frameworks in Purchasing and Supply Management (PSM). In total 20 maturity models published from authors with an academic or scientific background, 18 maturity models offered from consulting firms and 19 management frameworks of purchasing management were examined. Based on these preliminary findings the Purchasing and Supply Management Maturity Framework (PSM2F) was designed as a management framework including the assessment and interpretation of the PSM maturity in a company as well as concrete suggestions for the realization of the improvement initiatives that should lead to higher sophistication.

The presented results extend the scientific discussion about maturity in Purchasing and Supply Management by giving a comprehensive summary and critical appraisal of the published models and academic movements in this context. Even though it was not the goal to empirically verify or falsify the impact of single aspects of maturity in PSM to the overall corporate performance, the research results are offering a scientifically sound basis for such indepth empirical investigations.

Moreover, the research work offers concrete managerial implications. By clustering the main areas and indicators of high maturity in PSM, this paper answers the 
question "What are the main levers of a professional and strategic oriented PSM department?". This is a helpful guideline and orientation for purchasing executives, who focus on a continuous advancement of professionalism and innovation in the purchasing function.

\section{REFERENCES}

Aberdeen (2014), The CPO's Economic Agenda for 2014. Analyst Insight. Aberdeen Group. 02/2014, Download: http://www.aberdeen.com/research/8838/AI-cpo-economicagenda.aspx/content.aspx , 2014-07-30.

Adams, S. (2011), Forbes: Ranking of TOP Consulting Companies, Download:

http://www.forbes.com/sites/susanadams/2011/08/25/themost-prestigious-consulting-firms, 2014-02-12.

Anderson, M. and Katz, P. (1998), Strategic Sourcing. The International Journal of Logistics Management 9(1), pp. 1 -13 .

Appelfeller, W., and Buchholz, W. (2011), Supplier Relationship Management - Strategie, Organisation und IT des modernen Beschaffungsmanagements, $2^{\text {nd }}$ Edition, Gabler, Wiesbaden.

Arnolds, H., Heege, F. And Tussing, W. (1998), Materialwirtschaft und Einkauf. Praxisorientiertes Lehrbuch, Gabler, Wiesbaden.

Arnolds, H., Heege, F., Röh, C. and Tussnig, W. (2013), Materialwirtschaft und Einkauf: Grundlagen Spezialthemen - Übungen, $12^{\text {th }}$ Edition, Gabler, Wiesbaden.

A.T. Kearney (2011), Following the procurement leaders, Download: http://www.atkearney.at/procurement/ideasinsights/article/-

/asset_publisher/LCcgOeS4t85g/content/follow-theprocurement-leaders-seven-ways-to-lasting-results, 201408-20.

Axelsson, B., Rozemeijer, F. and Wynstra, F. (2006), The case for change, in Axelsson, B., Rozemeijer, F. and Wynstra, F. (eds), Developing sourcing capabilities, John Wiley \& Sons, West Sussex.

Bäck, S., Tschandl, M., Schentler, P. and Schweiger, J. (2007), Einkauf optimieren, Praxishandbuch, Effizienz und Effektivität in Einkauf und Logistik, FH JOANNEUM, Industrial Management/Industriewirtschaft, Kapfenberg.

Baier, C. (2008), The alignment performance link in Purchasing and Supply Management, Gabler, Wiesbaden.

Ballou, R. (1998), Business Logistics Management, $4^{\text {th }}$ Edition, Prentice Hall, Upper Saddle River.

Barry, J., Cavinato, J., Green, A. and Young, R. (1996), A development model for effective MRO procurement. International Journal of Purchasing and Materials Management, Volume 32(3), pp. 35 - 44.

Beamon, B. M. (2008), Sustainability and the Future of Supply Chain Management. Operations and Supply Chain Management, Volume 1(1), pp. 4 - 18.

Benton, W.C. (2010), Purchasing and Supply Chain Management, $2^{\text {nd }}$ Edition, McGraw-Hill, New York.

Bhote, K.R. (1989), Strategic Supply Management. A Blueprint for Revitalizing the Manufacturer-Supplier Relationship, amacon, New York.

BME, Bundesverband für Materialwirtschaft, Einkauf und Logistik e.V. (2011), Top-Kennzahlen im Einkauf, Best in Class 2011, Frankfurt.

Bowersox, D., Closs, D. and Stank, T. (1999), $21^{\text {st }}$ century logistics: making supply chain integration a reality, Council of Supply Chain Management Professionals, Oak Brook.

Burt, D., Dobler, D. and Starling, S. (2003), World Class Supply

Managment, McGraw-Hill, New York.
Burt, D. and Doyle, M. (1994), The American Keiretsu: A Strategic Weapon for Global Competitiveness, Econ, Irwin.

Brand Eins (2014), Unternehmensberater: Vom Besserwisser zum Bessermacher, Brand Eins 1(1), pp. 82 - 119.

Bruel, O. and Petit, F. (2005), Fonction achats: mesure et pilotage des performances - benchmarking des pratiques, Cahier de recherche HEC département MIL, Volume 4/20.

Cammish, R. and Keough, M. (1991), A strategic role for purchasing. McKinsey Quarterly, August, pp. $22-39$.

Champy, J. (1995), Reengineering im Management, campus, Frankfurt/New York.

Chiesa, V., Coughlan, P. and Voss, C.A. (1996), Development of a technical innovation audit. Journal of Product Innovation Management 13(2), pp. $105-136$.

Childerhouse, P., Deakins, E., Böhme, T., Towill, D., Disney, S. and Banomyong, R. (2011), Supply chain integration: an international comparison of maturity. Asia Pacific Journal of Marketing and Logistics 23(4), pp. 531 - 552.

Closs, D. and Mollenkopf, D. (2004), A global supply chain framework. Industrial Marketing Management 33(1), pp. $37-44$.

Cooper, M., Lambert and D., Pagh J. (1997), Supply Chain Management: More than a new name for Logistics. The International Journal of Logistics Management 8(1), pp. 1 $-14$

Cousins, P.D., Lawson, B. and Squire, B. (2006), An empirical taxonomy of purchasing functions. International Journal of Operations and Production Management 26(7), pp. 775 794.

Cousins, P., Lamming, R., Lawson, B. and Squire, B. (2008), Strategic supply management, Prentice Hall, Essex.

Cox, A., (1996), Regional competence and strategic procurement management. European Journal of Purchasing and Supply Management 2(1), pp. $57-70$.

Dobler, D and Burt, D. (1996), Purchasing and Supply Management, $6^{\text {th }}$ Edition, McGraw-Hill, New York.

EFQM, European Foundation for Quality Management (2006), Framework for Managing External Resources, Download: http://www.eipm.org/research/EFQM\%20EIPM\%20Frame work \%20for\%20Exc\%20Ext\%20Resources.pdf, 2014-0320

Ellram, L.M., Zsidisin, G.A., Siferd Perrot, S. and Stanley, M.J. (2002), The impact of purchasing and supply management activities on corporate success. The Journal of Supply Chain Management 38(4), pp. 4 - 17.

Eschenbach, R. (1990), Erfolgspotential Materialwirtschaft, C.H. Beck, Mainz.

Eßig, M. (2005), Perspektiven des Supply Managements, Springer, Berlin.

Fawcett, S., Magnan, G. and McCarter, M. (2008), A three-stage implementation model for supply chain collaboration. Journal of Business Logistics 29, pp. 93 - 112.

Freeman, V.T. and Cavinato, J.L. (1990), Fitting purchasing to the strategic firm: frameworks, processes, and values. Journal of Purchasing and Materials Management 26, pp. 6-10.

Gonzales-Benito, J. (2007), A theory of purchasing's contribution to business performance. Journal of Operations Management 25(4), pp. $901-917$.

Graaff, E. and Kolmos, A. (2007), Management of Change, Sense Publishers, Rotterdam.

Hartmann, E., Kerkfeld, D. and Henke, M. (2012), Top and bottom line relevance of purchasing and supply management. Journal of Purchasing \& Supply Management 18(1), pp. 22 -34 .

Heß, G. (2008), Supply-Strategien in Einkauf und Beschaffung: Systematischer Ansatz, und Praxisfälle, Gabler, Wiesbaden.

Kähkönen, A. K. (2011), Conducting a Case Study in Supply Management. Operations and Supply Chain Management $4(1)$, pp. $31-41$. 
Kanji, G. and Wong, A. (1999), Business Excellence model for supply chain management. Total Quality Management 10(8), pp. $1147-1168$.

Kaufmann, L. (2002), Purchasing and Supply Management - A conceptual Framework, in Hahn, D. and Kaufmann, 1. (eds), Handbuch industrielles Beschaffungsmanagement, $2^{\text {nd }}$ Edition, Gabler, Wiesbaden.

Keough, M. (1993), Buying your way to the top. McKinsey Quarterly, August, pp.41-62, Download: http://www.mckinsey.com/insights/operations/buying_your way to the top, 2014-07-24.

Klein, V., Bundesverband Materialwirtschaft, Einkauf und Logistik e.V. (2012), Top-Kennzahlen im Einkauf: Ergebnisse aus der Datenerhebung 2012, Best-in-Class-Werte, Frankfurt/Main.

Kluck, D. (1998), Materialwirtschaft und Logistik, SchäfferPoeschel, Stuttgart.

Kraljic, P. (1983), Purchasing must become supply management. Harvard Business Review 61(5), pp. $109-117$.

Kusaba, K., Moser, R. and Rodrigues, A. (2011), Low-cost country sourcing competence: a conceptual framework and empirical analysis. Journal of Supply Chain Management 47(4), pp. $73-93$.

Lockamy, A. and McCormack, K. (2004), The development of a supply chain management process maturity model using the concepts of business process orientation. Supply Chain Management: An International Journal 9(4), pp. 272 - 278.

Lysons, K. and Farrington, B. (2012), Purchasing and Supply Chain Management, $8^{\text {th }}$ Edition, Pearson Education Limited, Essex.

Monczka, R.M. and Trent, R.J. (1991), Global sourcing - a development approach. International Journal of Purchasing and Materials Management 27(2), pp. 2 - 8.

Monczka, R.M. and Trent, R.J. (1992), Worldwide sourcing: assessment and execution. International Journal of Purchasing and Materials Management 28(4), pp. 9-19.

Monczka, R., Handfield, R., Giunipero, L., Patterson, J. and Waters, D. (2010), Purchasing \& Supply Chain Management, $4^{\text {th }}$ Edition, Cengage Learning, Hampshire.

Netland, T. and Alfnes, E. (2011), Proposing a quick best practice maturity test for supply chain operations. Measuring Business Excellence 15(1), pp. 66 - 76.

Ortner, W., Hanusch, S. and Tschandl, M., (2011), AbnehmerLieferanten-Beziehungen optimieren: Management of Requirements in Collaborations, Leykam, Graz.

Ortner, W. and Schweiger, J. (2010), Management of Requirements in Collaborations, in Kersten, W., Blecker, T. and Lüthje, C (eds.), Pioneering Solutions in Supply Chain Management, ESV, Berlin.

Paulraj, A., Chen, I.J. and Flynn, J. (2006), Levels of strategic purchasing: impact on supply integration and performance. Journal of Purchasing and Supply Management 12(3), pp. $107-122$.

Porsche Consulting (2012), Lean Management im Einkauf, Download:

https://www.porscheconsulting.com/filestore.aspx/Porsched ownload.pdf?pool=pco\&type=download \&id=studieeinkauf \&lang $=$ de $\&$ filetype $=$ default $\&$ version $=18 \mathrm{c} 9903 \mathrm{a}-\mathrm{e} 18 \mathrm{e}-$ 44e3-a469-9b6c759977de, 2012-05-24.

Reck, R.F. and Long, B.G. (1988), Purchasing: a competitive weapon. Journal of Purchasing and Materials Management 24(3), pp. $2-8$.

Reyes, H. and Giachetti, R. (2010), Using experts to develop a supply chain maturity model in Mexico. Supply Chain Management: An International Journal 15(6), pp. $415-$ 424.

Roland Berger (2014), The CPO Agenda 2014, 01/2014, Download: http://www.rolandberger.com/media/pdf/Roland_Berger_T he_CPO_Agenda_20140130.pdf, 2014-08-10.
Operations and Supply Chain Management 8(1) pp. 11 - 21 @ 2015

Rousseau, D.M., Manning, J. and Denyer, D. (2008), Evidence in management and organizational science: assembling the field's full weight of scientific knowledge through syntheses. Academy of Management Annals 2(1), pp. 475 515 .

Rozemeijer, F.A., van Weele, A.J. and Weggeman, M. (2003), Creating corporate advantage through purchasing: toward a contingency model. The Journal of Supply Chain Management 39(4), pp. 4-13.

Sartor, M., Orzes, G., Nassimbeni, G., Jia, F. and Lamming, R (2013), International purchasing offices: Literature review and research directions. Journal of Purchasing \& Supply Management 20(1), pp. $1-17$.

Schentler, P. (2008), Beschaffungscontrolling in der kundenindividuellen Massenproduktion, Leykam, Graz.

Scheuing, E. (1989), Purchasing Management, Prentice Hall, New Jersey.

Schiele, H. (2007), Supply-management maturity, cost savings and purchasing absorptive capacity: Testing the procurementperformance link. Journal of Purchasing \& Supply Management 13(4), pp. $274-293$.

Schober, H., Middendorf, A. and Jahns, C. (2001), Neupositionierung des Einkaufs im Unternehmen: Der Integrierte St.Galler Beschaffungsmanagement-Ansatz. BA Beschaffung aktuell, Volume 2, Download: http://www.beschaffung-aktuell.de/home/larticle/16537505/27026762, 2007-07-14.

Schumacher, S., Schiele, H., Contzen, M. and Zachau, T. (2008), Die 3 Faktoren des Einkaufs, John-Wiley, Weinheim.

Schreyögg, G. (2007), Betriebswirtschaftslehre nur noch als Etikett? Betriebswirtschaftslehre zwischen Übernahme und Zersplitterung. ZfbF: Schmalenbachs Zeitschrift für betriebswirtschaftliche Forschung 59, Sonderheft 56, pp. $140-160$.

Schweiger, J., Ortner, W., Busse, K. and Dieringer, T. (2009), Roadmap to Procurement Excellence, Kapfenberg/Wien.

Schweiger, J. (2014), A theory-based perspective on Maturity Models in Purchasing and Supply Management, in Kersten, W., Blecker, T. and Ringle, C., Innovative Methods in Logistics and Supply Chain Management - Current Issues and Emerging Practices, epubli, Berlin.

Seuring. S., Müller, M., Westhaus, M. and Morana, R. (2005), Conducting a Literature Review - The Example of Sustainability in Supply Chains, in Kotzab, H., Seuring, S., Müller M. and Reiner, C (eds.), Research Methodologies in Supply Chain Management, Physica, Heidelberg.

Sollish, F. and Semanik, F. (2012), The procurements and supply manager's desk reference, $2^{\text {nd }}$ Edition, John-Wiley, New Jersey.

Spina, G., Caniato, F., Luzzini, D. and Ronchi, S. (2013), Past, present and future trends of purchasing and supply management: An extensive literature review. Industrial Marketing Management 42(8), pp. 1202 - 1212.

Spring Procurement (2010), Zukunft Einkauf - Trends in der Beschaffung, Download: http://www.springprocurement.com/studiezukunfteinkauf.p df, 2012-09-23.

Stolle, M. (2007), From Purchasing to Supply Management, Gabler, Wiesbaden.

Stollenwerk, A. (2012), Wertschöpfungsmanagement im Einkauf, Gabler, Wiesbaden.

Supply Chain Council (2012), Supply Chain Operations Reference SCOR® Model 11, Download: https://supplychain.org/f/028725604718/SCOR11PDF.pdf, 2013-10-27.

Syson, R. (1994), Purchasing for the nineties. BPICS Control, Feb/Mar, pp. 35 - 37.

Tate, W., Ellram, L. and Dooley, K. (2012), Environmental purchasing and supplier management (EPSM): Theory and practice. Journal of Purchasing \& Supply Management 18(3), pp. $173-188$. 
Trent, R. and Monczka, R. (2005), Achieving Excellence In Global Sourcing. MIT Sloan Management review 47(1), pp. $23-$ 32.

Ulrich, H. (1984), Management, Haupt, Bern.

Van Weele, A. (2010), Purchasing and Supply Chain Management, $5^{\text {th }}$ Edition, Cengage-Learning, Hampshire.

Voegele, A. and Schwientek, R. (2002), Purchasing EmPowerment, in Hahn, D. and Kaufmann, L. (eds.), Handbuch industrielles Beschaffungsmanagement, $2^{\text {nd }}$ Edition, Gabler, Wiesbaden Wildemann, H. (2008), Einkaufspotenzialanalyse: Programme zur partnerschaftlichen Erschließung von Rationalisierungspotenzialen. $2^{\text {nd }}$ Edition, TCW, München.

Vollrath, C. and Nase, A. (2003), Spitzenleistungen im Einkauf Der Einkaufs-Performance-Index 2002, in cooperation with the Institute of Technology Management University St. Gallen. Beschaffung aktuell (online), Download: http://www.beschaffung-aktuell.de/home//article/16537505/27024787/Spitzenleistungen-imEinkauf/art_co_INSTANCE_0000/maximized/, 2007-0917.
Vollrath, C. (2006), Spitzenleistungen im Einkauf, Der Weg zur Purchasing-Performance-Excellence (PPE): Eine branchenübergreifende Benchmarking Studie, A.D. Little in cooperation with the Institute of Technology Management University St. Gallen, http://www.adltechnology.com/uploads/tx_extthoughtleade rship/ADL_ppe_studienergebnisse.pdf, 2009-05-25.

Wallner, M. and Schweiger, J. (2012), Design of a framework for rationalizing the supplier base, in Blecker, T., Kersten, W., Ringle, C. (eds.), Pioneering supply chain design: a comprehensive insight into emerging trends, technologies and applications, ESV, Lohmar.

Wildemann, H. (2009), Leitfaden zur Einbindung der Beschaffungsmärkte in den Produktentstehungsprozess, $9^{\text {th }}$ Edition, TCW, München.

Wong, A. (2003), Achieving supply chain management excellence. Total Quality Management 14(2), pp. 151 - 159.

Wynstra, F. (2010), What did we do, who did it and did it matter? A review of fifteen volumes of the (European) Journal of Purchasing and Supply Management. Journal of Purchasing \& Supply Management 16(4), pp. 279-292.

Jörg Schweiger (M.Sc. in International Supply Management and M.Sc. in Industrial Management) is a Doctoral Researcher in the Department of Electrical, Managerial and Mechanical Engineering at the University of Udine in Italy. His research interests are in the areas of maturity in purchasing and supply management and the change process within purchasing departments. He has published on these topics in numerous conference in Europe and the USA and academic as well as managerial books. Next to his scientific career in researching and teaching in different universities, he is also responsible for the strategic purchasing department of an Austrian high-tech company. 